\title{
Comparative analysis of phenolic acids and flavonoids in shoot cultures of Eryngium alpinum L.: an endangered and protected species with medicinal value
}

\author{
Małgorzata Kikowska ${ }^{1}$ D $\cdot$ Barbara Thiem ${ }^{1} \cdot$ Agnieszka Szopa $^{2} \cdot$ Marta Klimek-Szczykutowicz $^{2} \cdot$ Monika Rewers $^{3}$. \\ Elwira Sliwinska ${ }^{3} \cdot$ Halina Ekiert ${ }^{2}$
}

Received: 30 November 2018 / Accepted: 14 August 2019 / Published online: 21 August 2019

(c) The Author(s) 2019

\begin{abstract}
Phenolic acids and flavonoids, important bioactive compounds of polyphenols, play a significant role in plants; their impact, mainly as antioxidants, on human health have been of great interest in recent years. The genetically uniform shoots of Eryngium alpinum L. cultured in vitro, developed via axillary buds and regenerated from callus tissue, maintained on the media supplemented with various plant growth regulators, were subjected to the phenolic acids and flavonoids quantitative analysis applying HPLC-DAD technique. In vitro cultures give the opportunity to perform the phytochemical studies on the protected species without harvesting the plant material from natural environment. Depending on the hormonal supplementation, the biomass from the shoot cultures accumulated from 11.41 to 25 times more phenolic acids [the total content ranged from 158.66 to $1817.96 \mathrm{mg} / 100 \mathrm{~g}$ of dry weight (DW)] and from 6.8 to 11.8 times more flavonoids (the total content ranged from 29.30 to $51.30 \mathrm{mg} / 100 \mathrm{~g} \mathrm{DW}$ ) than the shoots from the soil-grown plant. The polyphenols present in the shoot cultures include two phenolic acids: 3,4-dihydroxyphenylacetic and caffeic, four depsides: caftaric, neochlorogenic, chlorogenic, isochlorogenic, and rosmarinic acids, and flavonoids: aglycone-isoquercetin and glucoside-quercitrin. Most of them (apart from chlorogenic and rosmarinic acids) were detected for the first time in this species cultured in vitro. To our best knowledge, the present report is the first one that discusses establishment of Eryngium alpinum L. in vitro cultures and the shoot and callus biomass capacity to produce two subgroups of polyphenols i.e. phenolic acids and flavonoids.
\end{abstract}

\section{Key message}

This is the first report on establishment of Eryngium alpinum in vitro cultures and the shoot and callus biomass capacity to produce polyphenols_-phenolic acids and flavonoids.

Keywords Alpine eryngo $\cdot$ Callus culture $\cdot$ Flavonoids $\cdot$ HPLC-DAD analysis $\cdot$ Phenolic acids $\cdot$ Shoot culture

\section{Introduction}

Eryngium alpinum L., a perennial species characterized by blue amethyst colored flowers, belongs to the Saniculoideae subfamily of the Apiaceae family (Cullen et al. 1997). It

Communicated by Wagner Campos Otoni.

Małgorzata Kikowska

kikowska@ump.edu.pl

Barbara Thiem

bthiem@ump.edu.pl

1 Department of Pharmaceutical Botany and Plant Biotechnology, Poznan University of Medical Sciences, 14

Św. Marii Magdaleny St., 61-861 Poznań, Poland
2 Chair and Department of Pharmaceutical Botany, Jagiellonian University, Collegium Medicum, 9 Medyczna St., 30-688 Kraków, Poland

3 Laboratory of Molecular Biology and Cytometry, Department of Agricultural Biotechnology, UTP University of Science and Technology, Prof. S. Kaliskiego Ave. 7, 85-789 Bydgoszcz, Poland 
can be found across the European Alps, in open and sunny habitats, at altitudes between 1500 and $2000 \mathrm{~m}$ a. s. 1. The population of the plant is in decline due to its cutting for ornamental purposes and collecting seeds; recreational activities, such as skiing, are degrading its habitat as well. Spring grazing, seasonal mowing, agricultural practices, mowing of meadows by farmers could have an enormous impact on the reproductive success (Andrello et al. 2017). The species is listed on Annex II of the Habitats Directive and under Appendix I of the Convention on the Conservation of European Wildlife and Natural Habitats (the Bern Convention); it is protected by the European Habitat Directive of Natura 2000, the national red lists of protected species and it is also considered vulnerable by International Union for Conservation of Nature (Gygax et al. 2013).

Due to the unavailability of the plant material, little research on this taxon was carried out. Only a few papers indicated the presence of phenolic acids, flavonoids and the essential oil in the organs of the soil-grown plant (Crowden et al. 1969; Le Claire et al. 2005; Dunkic et al. 2013). The identification of two flavonoids, namely quercetin and kaempferol, in the leaves was described by Crowden et al. (1969). The roots of alpine eryngo are known to contain chlorogenic acid, $R-(+)$-rosmarinic acid and its derivative- $R-(+)-3^{\prime}-O-$ $\beta$-D-glucopyranosyl rosmarinic acid (Le Claire et al. 2005). Moreover, the crude extract of the roots demonstrated moderate radical scavenging activity toward 2,2-diphenyl-1-picrylhydrazyl (Le Claire et al. 2005). The dominant components identified in the essential oil obtained by hydrodistillation of the aerial parts were caryophyllene, bibyclogermacrene and germacrene (sesquiterpene hydrocarbons), cariophyllene oxide and $\alpha$-bisabolol (oxygenated sesquiterpenes), and camphor (oxygenated monoterpene). The essential oil showed promising antiphytoviral effect, which is probably correlated with a high content of $\beta$-caryophyllene and caryophyllene oxidate (Dunkic et al. 2013).

The Global Strategy for Plant Conservation promotes the development of both in situ and ex situ conservation methods of rare and vulnerable species. The in vitro cultures of E. alpinum are a part of the collection of protected species of the Department of Pharmaceutical Botany and Plant Biotechnology of Poznan University of Medical Sciences (PUMS). The use of in vitro cultures of alpine eryngo allows for conducting the phytochemical analyses and testing further biological activities of this species without devastating its natural sites to obtain the plant material.

There are only a few reports on the in vitro cultures of Eryngium species, namely on E. foetidum (Arockiasamy and Ignacimuthu 1998; Ignacimuthu et al. 1999; Arockiasamy et al. 2002; Martin 2004; Chandrika et al. 2011), E. planum (Kikowska et al. 2012, 2015; Thiem et al. 2013), E. maritimum (Kikowska et al. 2014), E. campestre (Kikowska et al. 2016), and E. viviparum (Ayuso et al. 2019).
The aim of the study was to obtain the shoot biomass of E. alpinum under in vitro conditions and to comprehensively analyze the quality and quantity of phenolic acids and flavonoids. Our study involved the shoots from the selected media with various hormonal supplementation. The shoots were developed in two ways: from meristematic tissue of the lateral buds from the soil-grown plant and via indirect morphogenesis (from the callus). Then the shoots were multiplied by means of the axillary bud proliferation technique.

The protocol allows for harvesting the high-quality raw material from alpine eryngo without decreasing the medicinal quality and quantity of bioactive compounds.

\section{Materials and methods}

\section{Source of plant material origin}

The fruits of E. alpinum collected from the botanical gardens had very mature seeds. As it is known from literature, the seeds of this taxon become dormant soon after harvest (Njenga 1995). Therefore, the seedlings that could become the primary explants for the further biotechnological research were not obtained in vitro. For this reason, the fragments of the cuttings obtained from the Botanical Garden of the Department of Medicinal and Cosmetic Products of Poznan University of Medical Sciences in $2016\left(52^{\circ} 25^{\prime} 31.1^{\prime \prime} \mathrm{N}\right.$ $\left.16^{\circ} 53^{\prime} 50.4^{\prime \prime} \mathrm{E}\right)$ and from Adam Mickiewicz Botanical Garden in Poznań in 2017 (52 25'13.1"N 16 52'44.9"E) were used for the initiation of cultures. The voucher specimens were deposited at the Department of Pharmaceutical Botany and Plant Biotechnology of PUMS under the following numbers: H-AP-2016-101 and H-AP-2017-102.

\section{Establishment of in vitro cultures}

The soft shoots with lateral buds were harvested; the collected explants were washed in double-distilled water (DDW) for $5 \mathrm{~min}$, and $70 \%$ ethanol for $30 \mathrm{~s}$, and then lightly disinfected with $200 \mathrm{~mL}$ of $50 \%$ (v/v) bleach solution (3.3\% active calcium hypochlorite) with 2-3 drops of Tween 80 for $5 \mathrm{~min}$. The surface disinfected shoots were taken to a laminar air-cabin and washed with autoclaved DDW to complete three separate washes of 3 min duration each. The shoots were also trimmed to remove all unwanted fragments. After the final wash, the individual explants $(1-2 \mathrm{~cm})$ were transferred to $250 \mathrm{~cm}^{3}$ flasks with $50 \mathrm{~cm}^{3}$ of a solidified basal MS medium (Murashige and Skoog 1962) with 3\% sucrose and plant growth regulators (PGRs), namely 6-benzylaminopurine (BAP), indole-3-acetic acid (IAA) and $\mathrm{GA}_{3}$ (gibberellic acid) at concentrations of $0.5 \mathrm{mg} / \mathrm{L}$ or $1.0 \mathrm{mg} / \mathrm{L}$ (Table 1), $0.76 \%$ agar and $\mathrm{pH}$ set to 5.8 prior to autoclaving at $121{ }^{\circ} \mathrm{C}, 105 \mathrm{kPa}$ for $20 \mathrm{~min}$. All PGRs as well as agar 
were purchased from Sigma-Aldrich (Saint Louis, USA). The culture vessels were placed in a growth chamber $\left(21^{\circ} \mathrm{C}\right.$; with a $16 \mathrm{~h} \mathrm{light} / 8 \mathrm{~h}$ dark photoperiod; $55 \mu \mathrm{mol} / \mathrm{m}^{2} \mathrm{~s}$ photon flux density provided by cool-white fluorescent lamps) and subcultured every 5 weeks. Multiplication of the shoots was replicated three times for each hormonal treatment using at least ten explants (2-3 per flask).

The leaves $\left(1 \mathrm{~cm}^{2}\right.$ segments) from the same individual were used for the callus initiation. The whole leaves were washed in DDW for 5 min and 70\% ethanol for $30 \mathrm{~s}$, and then disinfected with $300 \mathrm{~mL}$ of $70 \%(\mathrm{v} / \mathrm{v})$ bleach solution (3.3\% active calcium hypochlorite) with 2-3 drops of Tween 80 for $7 \mathrm{~min}$. The surface disinfected leaves were washed three times for $3 \mathrm{~min}$. After the final wash, the leaf explants were transferred to $150 \mathrm{~cm}^{3}$ flasks containing $30 \mathrm{~cm}^{3}$ of a solidified MS basal medium with 3,6-dichloro2-metoxybenzoic acid (dicamba, Dic $1.0 \mathrm{mg} / \mathrm{L}$ ) and thidiazuron (TDZ $0.5 \mathrm{mg} / \mathrm{L}$ ). The callus clumps observed after three weeks of culture on the MS medium with Dic and TDZ were collected, divided into the clumps about the same size $\left(1 \mathrm{~cm}^{2}\right)$ and distributed on the regeneration MS media $\left(150 \mathrm{~cm}^{3}\right.$ flasks containing $30 \mathrm{~cm}^{3}$ aliquots of medium) with the selected PGRs: BAP, IAA and 2,4-D (2,4-dichlorophenoxyacetic acid) at different concentrations. The number of shoots regenerated from a callus clump was recorded. The callus cultures and callus-derived shoots were grown under the same light and temperature conditions as the shoot cultures obtained from the lateral buds.

\section{HPLC-DAD analysis}

The dried and pulverized plant material (the shoots from the ground plant and in vitro cultures) and callus biomass (each sample of $0.5 \mathrm{~g} \mathrm{DW}$ ) of E. alpinum was extracted by sonication (Polsonic $® 3$, Poland) in methanol (5 mL) for $30 \mathrm{~min}$ at room temperature. The analysis of phenolic acids and flavonoids in the extracts was performed by applying a validated
HPLC-DAD method (according to Ellnain-Wojtaszek and Zgorka 1999; Sułkowska-Ziaja et al. 2017). The details of HPLC-DAD analysis, equipment and conditions were described previously (Szopa et al. 2017a, b): system HPLCDAD (Merck-Hitachi); Purospher RP-18e analytical column $(4 \times 250 \mathrm{~mm}, 5 \mathrm{~mL}$; Merck); mobile phase consisted of: A-methanol: $0.5 \%$ acetic acid $(1: 4 \mathrm{v} / \mathrm{v})$ and $\mathrm{B}$-methanol; gradient program: 0-20 min, 0\% B; 20-35 min, 0-20\% B; 35-45 min, 20-30\% B; 45-55 min, 30-40\% B; 55-60 min, 40-50\% B, 60-65 min, 50-75\% B; and 65-70 min, 75-100\% $\mathrm{B}$, with a hold time of $15 \mathrm{~min}$, at $25^{\circ} \mathrm{C}$; flow rate $1 \mathrm{~mL} / \mathrm{min}$, injection volume $10 \mu \mathrm{L}$.

The identification of compounds was carried out on the basis of UV spectra $(\lambda=200-400 \mathrm{~nm}), \mathrm{R}_{\mathrm{t}}$ values and an internal standard method, with the application of reference substances. The quantification was performed by comparison of the peak area measurements to the standard curves. For the analyses, the following standards of phenolic acids from Sigma-Aldrich (Saint Louis, USA) were used: 3,4-dihydroxyphenylacetic acid, caftaric acid, caffeic acid, chlorogenic acid, $o-, m-, p$-coumaric acids, ferulic acid, gallic acid, gentisic acid, hydrocaffeic acid, $p$-hydroxybenzoic acid, isochlorogenic acid, isoferulic acid, neochlorogenic acid, protocatechuic acid, rosmarinic acid, salicylic acid, sinapic acid, syringic acid and vanillic acid, and benzoic and cinnamic acids (precursors of phenolic acids) $(23 \mathrm{com}$ pounds). The applied flavonoid standards included aglycones: isorhamnetin kaempferol, luteolin, quercetin, rhamnetin, and myricetin and glycosides: apigetrin, cynaroside, hyperoside, populnin, quercitrin, rutin, trifolin, and vitexin (14 compounds) (Sigma-Aldrich, Saint Louis, USA).

\section{Genome size estimation}

The leaves of in vitro multiplied shoots, the shoots regenerated from the callus and callus biomass were used for the nuclear DNA content estimation. A nuclei isolation buffer
Table 1 The effect of PGRs on (BAP benzylamninopurine, IAA indole-3-acetic acid, $\mathrm{GA}_{3}$ gibberellic acid) on Eryngium alpinum L. shoot proliferation via axillary bud development on MS media after 7 weeks of culture

\begin{tabular}{|c|c|c|c|c|c|}
\hline \multicolumn{3}{|l|}{ MS } & \multirow{2}{*}{$\begin{array}{l}\text { Explants that pro- } \\
\text { liferated buds (\%) }\end{array}$} & \multirow{2}{*}{$\begin{array}{l}\text { Shoot no./ } \\
\text { explant ( } \pm \\
\text { SE) }\end{array}$} & \multirow[t]{2}{*}{ Shoot length $(\mathrm{cm} \pm \mathrm{SE})$} \\
\hline $\mathrm{BAP}(\mathrm{mg} / \mathrm{L})$ & IAA (mg/L) & $\mathrm{GA}_{3}(\mathrm{mg} / \mathrm{L})$ & & & \\
\hline- & - & - & 58 & $5.60 \pm 0.48^{\mathrm{ab}}$ & $2.29 \pm 0.14^{\mathrm{b}}$ \\
\hline 1.0 & - & - & 100 & $3.89 \pm 0.26^{\mathrm{c}}$ & $2.54 \pm 0.09^{\mathrm{bc}}$ \\
\hline 1.0 & 0.5 & - & 100 & $5.25 \pm 0.21^{\mathrm{ab}}$ & $2.71 \pm 0.11^{\mathrm{c}}$ \\
\hline 1.0 & 1.0 & - & 100 & $5.68 \pm 0.31^{\mathrm{ab}}$ & $1.46 \pm 0.04^{\mathrm{d}}$ \\
\hline 1.0 & 1.0 & 1.0 & 100 & $4.96 \pm 0.22^{\mathrm{bc}}$ & $2.66 \pm 0.15^{\mathrm{c}}$ \\
\hline 1.0 & 0.5 & 1.0 & 100 & $6.18 \pm 0.45^{\mathrm{a}}$ & $3.53 \pm 0.10^{\mathrm{a}}$ \\
\hline 1.0 & 1.0 & 0.5 & 100 & $5.72 \pm 0.22^{\mathrm{ab}}$ & $1.39 \pm 0.04^{\mathrm{d}}$ \\
\hline 1.0 & 0.5 & 0.5 & 95 & $6.06 \pm 0.31^{\mathrm{ab}}$ & $1.61 \pm 0.05^{\mathrm{d}}$ \\
\hline 0.5 & 0.5 & 0.5 & 86 & $4.93 \pm 0.38^{\mathrm{bc}}$ & $1.57 \pm 0.06^{\mathrm{d}}$ \\
\hline
\end{tabular}

Mean values with a column with the same letter are not significantly different at $P=0.05$ (Duncan's Multiple Range Test) 
(Galbraith et al. 1983) with 1\% (v/v) polyvinylpyrrolidone (PVP-10), propidium iodide (PI; $50 \mu \mathrm{g} / \mathrm{cm}^{3}$ ) and ribonuclease A $\left(50 \mu \mathrm{g} / \mathrm{cm}^{3}\right)$ was used. Petunia hybrida $\mathrm{P} \times \mathrm{Pc} 6$ (2.85 pg/2C; Marie and Brown 1993) was used as an internal standard. For each sample, 5000-8000 nuclei were analysed using a CyFlow SL Green flow cytometer (Partec GmbH, Münster, Germany) equipped with a high-grade solid-state laser with green light emission at $532 \mathrm{~nm}$, a long-pass filter RG 590 E, DM 560 A as well as with side (SSC) and forward (FSC) scatters using linear amplification. FloMax software (Partec GmbH, Münster, Germany) was used. The analyses were replicated at least three times for each plant material. The coefficient of variation (CV) of $\mathrm{G}_{0} / \mathrm{G}_{1}$ peak of E. alpinum ranged from 3.2 to $4.6 \%$. The nuclear DNA content was calculated using the linear relationship between the ratio of the $2 \mathrm{C}$ peak positions $E$. alpinum/P. hybrida on a histogram of fluorescence intensities.

\section{Statistical analysis}

The data were analysed using a one-way analysis of variance (ANOVA) and the statistical significance was determined applying Duncan's POST-HOC test ( $P$-value of 0.05). All the analyses were conducted employing STATISTICA v. 13 (StatSoft, Inc. 2015).

\section{Results and discussion}

To our best knowledge Eryngium alpinum L. was introduced into the in vitro cultures for the first time and the shoot cultures were established in our laboratory to study their capability of producing desired polyphenols, i.e. phenolic acids and flavonoids.

All the tested hormonal treatments had a significant impact on shoot multiplication of alpine eryngo via axillary bud development (Fig. 1a-d). However, the induction percentage of the new shoots was relatively low for the explants maintained on the MS medium without PGRs (58\%) comparing with those cultured on the enriched media (86-100\%, Table 1). The highest multiplication rate $(6.18 \pm 0.45)$ was achieved for the explants placed on MS with BAP $1.0 \mathrm{mg} / \mathrm{L}$, IAA $0.5 \mathrm{mg} / \mathrm{L}$ and $\mathrm{GA}_{3} 1.0 \mathrm{mg} / \mathrm{L}$ (Fig. 1c, d). It is worth noticing that those shoots were also the longest $(3.5 \mathrm{~cm}$; Table 1). The regenerated shoots were vigorous and welldeveloped. In case of E. planum, the highest mean number of shoots developed from axillary buds was higher, i.e. $15.58 \pm 0.54-17.10 \pm 0.60$ shoots per explant, depending on the culture media: MS + BAP $1.0 \mathrm{mg} / \mathrm{L}+\mathrm{IAA} 1.0 \mathrm{mg} / \mathrm{L}$ or MS + BAP $1.0 \mathrm{mg} / \mathrm{L}+\mathrm{IAA} 0.1 \mathrm{mg} / \mathrm{L}$ (Thiem et al. 2013). For $E$. campestre, more shoots $(13.30 \pm 3.73)$ were obtained when cultured on the same media composition (Kikowska et al. 2016). These two species were relatively easy to culture and exhibited a great potential of morphogenetic response. A completely different pattern of morphogenetic response was observed for E. maritimum (Kikowska et al. 2014) and E. alpinum (present studies)—rare and protected species living in extremely difficult climatic and soil conditions and exhibiting problems with seed germination. Although the fruits were subjected to scarification and stratification, the seedlings form the seeds could not be obtained for both species. The efficiency of shoot multiplication for E. maritimum varied between $1.2 \pm 0.20$ and $4.4 \pm 0.24$ shoots per explant on different media variants (Kikowska et al. 2014).

In our studies, the first sights of the callus induction were observed after 3 weeks of culture on MS with Dic $1.0 \mathrm{mg} / \mathrm{L}$ and TDZ $0.5 \mathrm{mg} / \mathrm{L}$ (Fig. 1e-f). The callus arising from the leaf explants was green, compact and hard. The first shoots arrived on the MS regeneration media with BAP/IAA/2,4$\mathrm{D}$ after 2 weeks of culture. The callus-derived shoots were not highly-multiplied, relatively low, and with leaves of narrow blades (Fig. 1g). The regeneration media proved to be effective at converting callus tissue into the shoots with the efficiency ranging from $2.60 \pm 0.31$ to $4.11 \pm 0.54$ shoots per callus clump; the best result was observed for the explants cultured applying BAP $1.0 \mathrm{mg} / \mathrm{L}$ and 2,4-D $1.0 \mathrm{mg} / \mathrm{L}$. The MS medium without PGRs turned out to be the least effective (Table 2). There are no reports on callus induction and indirect organogenesis in Eryngium species. The influence of BAP and 2,4-D on callus mediated shoot regeneration was evaluated for some medicinal plants: Melicope lunu-ankenda (Gaertn.) Merr. (Rahman et al. 2015), Eclipta alba (L.) Hassk (Sharma et al. 2013) or Arnica montana L. (Petrova et al. 2011).

The confirmation of genetic fidelity is of importance in plants used as a source of biological active metabolites. In our study the 2C DNA content of E. alpinum biomass-the leaves from the shoots developed from the axillary buds (on the media with and without PGRs) as well as regenerated from the callus and in the callus was similar and ranged from $2.342 \pm 0.017$ to $2.363 \pm 0.011$. There were no significant differences in DNA content between the plant material (Table 3 ). The results concerning the genome size stability were notably consistent with our previous studies on other Eryngium species (Thiem et al. 2013; Kikowska et al. 2014, 2016).

The harvested shoots and callus biomass as well as the shoots from the soil-grown plants were subjected to the phytochemical analysis by HPLC-DAD method of bioactive polyphenolic compounds, i.e. phenolic acids (PAs) (23 compounds tested) and flavonoids (Fs) (14 compounds tested) (Table 4; Figs. 2, 3).

The presence of 3,4-dihydroxyphenylacetic $(13.2 \mathrm{mg} / 100 \mathrm{~g} \mathrm{DW}$ ) and small amounts (below $0.4 \mathrm{mg} / 100 \mathrm{~g} \mathrm{DW}$ ) of depsides: chlorogenic, isochlorogenic and rosmarinic acids was confirmed in the extracts from the 


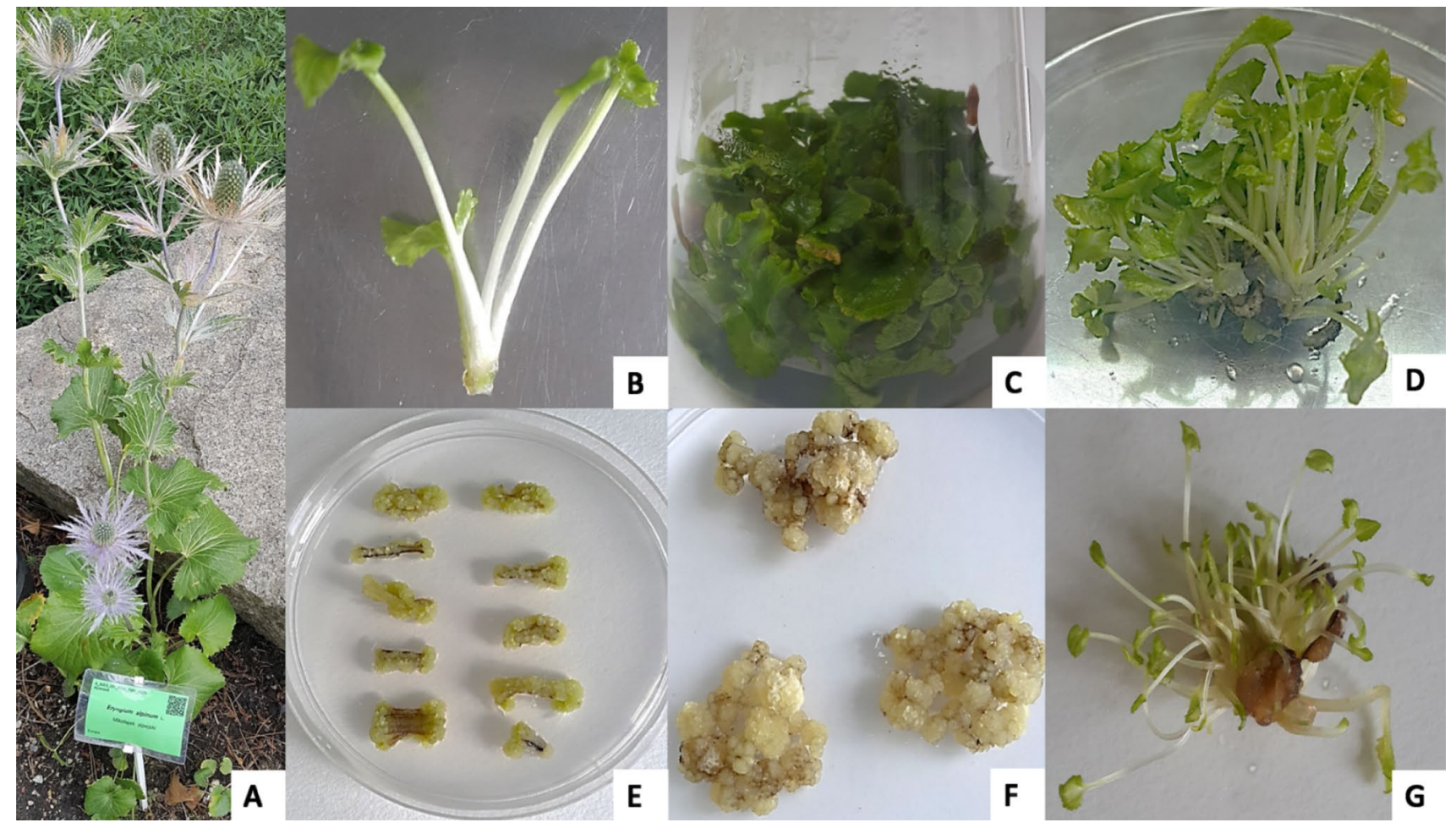

Fig. 1 Eryngium alpinum L. a Donor plant from Adam Mickiewicz Botanical Garden; b Single shoot established in vitro; c Multiplied shoots on MS + BAP $1.0 \mathrm{mg} / \mathrm{L}+\mathrm{IAA} 0.5 \mathrm{mg} / \mathrm{L}+\mathrm{GA}_{3} 0.5 \mathrm{mg} / \mathrm{L} ; \mathbf{d}$ Multiplied shoots on MS+BAP $1.0 \mathrm{mg} / \mathrm{L}+\mathrm{IAA} 0.5 \mathrm{mg} / \mathrm{L}+\mathrm{GA}_{3}$
$1.0 \mathrm{mg} / \mathrm{L}$; e Callus induction on MS + Dic $1.0 \mathrm{mg} / \mathrm{L}+\mathrm{TDZ} 0.5 \mathrm{mg} / \mathrm{L}$; f Callus clumps on MS + BAP $1.0 \mathrm{mg} / \mathrm{L}+2,4-\mathrm{D} 1.0 \mathrm{mg} / \mathrm{L}$; g Callusderived shoots on MS + BAP $1.0 \mathrm{mg} / \mathrm{L}+2,4-\mathrm{D} 1.0 \mathrm{mg} / \mathrm{L}$

Table 2 The effect of PGRs (BAP benzylamninopurine, IAA indole-3-acetic acid, 2,4-D 2,4 dichlorophenoxyacetic acid) on Eryngium alpinum L. shoot regeneration from callus on MS media after 7 weeks of culture

\begin{tabular}{|c|c|c|c|c|c|}
\hline \multicolumn{3}{|l|}{ MS } & \multirow{2}{*}{$\begin{array}{l}\text { Explants that prolifer- } \\
\text { ated buds }(\%)\end{array}$} & \multirow[t]{2}{*}{ Shoot no./callus $( \pm \mathrm{SE})$} & \multirow[t]{2}{*}{ Shoot length $(\mathrm{cm} \pm \mathrm{SE})$} \\
\hline $\mathrm{BAP}(\mathrm{mg} / \mathrm{L})$ & IAA $(\mathrm{mg} / \mathrm{L})$ & 2,4-D (mg/L) & & & \\
\hline- & - & - & 58 & $1.82 \pm 0.15^{\mathrm{c}}$ & $1.98 \pm 0.08^{\mathrm{a}}$ \\
\hline 1.0 & - & - & 76 & $2.60 \pm 0.31^{\mathrm{b}}$ & $1.73 \pm 0.09^{\mathrm{b}}$ \\
\hline 2.0 & - & - & 83 & $2.61 \pm 0.33^{\mathrm{b}}$ & $1.60 \pm 0.06^{\mathrm{bc}}$ \\
\hline 1.0 & 0.5 & - & 89 & $3.20 \pm 0.39^{\mathrm{ab}}$ & $1.51 \pm 0.04^{\mathrm{c}}$ \\
\hline 1.0 & 1.0 & - & 100 & $3.15 \pm 0.23^{\mathrm{ab}}$ & $1.57 \pm 0.04^{\mathrm{bc}}$ \\
\hline 2.0 & 2.0 & - & 100 & $3.12 \pm 0.20^{\mathrm{ab}}$ & $1.48 \pm 0.05^{\mathrm{c}}$ \\
\hline 1.0 & - & 0.5 & 100 & $2.90 \pm 0.23^{\mathrm{b}}$ & $1.74 \pm 0.06^{\mathrm{b}}$ \\
\hline 1.0 & - & 1.0 & 100 & $4.11 \pm 0.54^{\mathrm{a}}$ & $1.92 \pm 0.09^{\mathrm{a}}$ \\
\hline 2.0 & - & 2.0 & 100 & $3.10 \pm 0.38^{\mathrm{ab}}$ & $1.52 \pm 0.04^{\mathrm{c}}$ \\
\hline
\end{tabular}

Mean values with a column with the same letter are not significantly different at $P=0.05$ (Duncan's Multiple Range Test)

shoots of the soil-grown plants from PAs (Table 4). In these extracts the low amount of isoquercetin $(4.47 \mathrm{mg} / 100 \mathrm{~g} \mathrm{DW})$ was also detected (Table 5). The presence of seven compounds including two phenolic acids i.e. 3,4-dihydroxyphenylacetic and caffeic as well as five depsides i.e. caftaric, neochlorogenic, chlorogenic, isochlorogenic, and rosmarinic acids was confirmed in the extracts from the in vitro shoots and callus cultures from PAs (Table 4). Aglycone-isoquercetin and glucoside-quercitrin were confirmed in the shoot cultures form Fs. Fs were not detected in the callus cultures (Table 5).

In the present study, the shoots propagated under in vitro condition produced from 11.41 to 25.10 times more PAs than the shoots from the ground plant $(158.66-349.12 \mathrm{mg} / 100 \mathrm{~g}$ 
Table 3 Nuclear DNA content in leaves from in vitro-derived/regenerated shoots and callus of Eryngium alpinum L.

\begin{tabular}{ll}
\hline Plant material & DNA content $(\mathrm{pg} / 2 \mathrm{C} \pm \mathrm{SD})$ \\
\hline $\begin{array}{l}\text { Leaf of shoot culture (MS without } \\
\text { PGRs) }\end{array}$ & $2.360 \pm 0.017 \mathrm{~ns}$ \\
Leaf of shoot culture (MS with PGRs) $^{\mathrm{b}}$ & $2.363 \pm 0.011$ \\
Leaf of callus-regenerated shoots $^{\mathrm{c}}$ & $2.357 \pm 0.011$ \\
Callus $^{\mathrm{d}}$ & $2.342 \pm 0.017$ \\
\hline
\end{tabular}

$n s$ no significant differences at $P=0.05$

${ }^{\text {a }}$ Shoot culture on MS without PGRs

${ }^{\mathrm{b}}$ Shoot culture on $\mathrm{MS}+\mathrm{BAP} 1.0 \mathrm{mg} / \mathrm{L}+\mathrm{IAA} \quad 0.5 \mathrm{mg} / \mathrm{L}+\mathrm{GA}_{3}$ $1.0 \mathrm{mg} / \mathrm{L}$

${ }^{\mathrm{c}}$ Shoots regenerated from callus on $\mathrm{MS}+\mathrm{BAP} 1.0 \mathrm{mg} / \mathrm{L}+2,4-\mathrm{D}$ $1.0 \mathrm{mg} / \mathrm{L}$

${ }^{\mathrm{d}}$ Callus on MS + BAP $1.0 \mathrm{mg} / \mathrm{L}+2,4 \mathrm{D} 1.0 \mathrm{mg} / \mathrm{L}$

DW and $13.91 \mathrm{mg} / 100 \mathrm{~g} \mathrm{DW}$, respectively). At the same time, their composition was richer in caftaric acid, neochlorogenic acid and caffeic acid in comparison with the soilgrown plant material. Generally, in the in vitro material, 3,4-dihydroxyphenylacetic acid, chlorogenic acid (CGA) and rosmarinic acid (RA) were the quantitatively dominant PAs. Surprisingly, the content of CGA and RA was disproportionately lower in the shoots of the ground plant than in the shoots cultured in vitro. The content of the selected phenolic acids has been already measured in the different species of Eryngium including E. planum (Kikowska et al. 2012, 2015; Thiem et al. 2013), E. maritimum (Kikowska et al. 2014) and E. campestre (Kikowska et al. 2016). The three phenolic acids, i.e. rosmarinic acid (RA), chlorogenic acid (CGA) and caffeic acid (CA), were detected in the plant material of $E$. planum. The highest content of the sum of RA, CGA and CA was found in the biomass from the in vitro cultures (shoots and roots) and was considerably higher than in the shoots and roots of the ground plant (Kikowska et al. 2012; Thiem et al. 2013). For E. maritimum the content of RA and CGA was higher in the shoots and roots from the in vitro cultures than in the analogous organs of the ground plant (6.75 and 12 times, respectively). In case of E. campestre, the sum of RA, its hexoside and CGA in the biomass from the shoot culture was lower than in the shoots of the ground plant (Kikowska et al. 2016).

In this study, the best source of CGA and RA was admittedly the callus with the impressive amount of both, especially of RA $(1429.28 \pm 74.29 \mathrm{mg} / 100 \mathrm{~g} \mathrm{DW}$ and $546.92 \pm 34.90$, depending on the tested medium). Moreover, the callus maintained on induction medium contained a higher amount of PAs (1817.96 mg/100 g DW) than the callus cultured on regeneration medium $(777.55 \mathrm{mg} / 100 \mathrm{~g}$ DW), but the shoots regenerated from it were characterized by the lowest content of PAs (158.66 mg/100 g DW), which was probably related to the influence of different PGRs (2,4-D instead of IAA and $\left.\mathrm{GA}_{3}\right)$. As it turned out, the tissue (callus), which was used only for the regeneration of shoots, was the richest source of PAs (Table 4). The high production of PAs in the callus cultures was proved for some other species. The studies on Schisandra chinensis were performed on tissue at different stages of organogenesis in vitro on a few variants of the MS

Table 4 The content of selected phenolic acids in the shoot cultures and callus of Eryngium alpinum L.

\begin{tabular}{|c|c|c|c|c|c|c|c|c|c|}
\hline \multirow{2}{*}{$\begin{array}{l}\text { Phenolic } \\
\text { acids }\end{array}$} & \multicolumn{7}{|c|}{ Shoots (mg/100 g DW) } & \multicolumn{2}{|c|}{ Callus (mg/100 g DW) } \\
\hline & G & $\mathrm{P} 1$ & $\mathrm{P} 2$ & $\mathrm{P} 3$ & $\mathrm{P} 4$ & P5 & $\mathrm{PC} 1$ & $\mathrm{C} 1$ & $\mathrm{C} 2$ \\
\hline Caftaric acid & - & $8.20 \pm 0.10$ & $7.65 \pm 0.15$ & $2.82 \pm 0.06$ & $14.60 \pm 0.79$ & $14.82 \pm 1.10$ & $8.56 \pm 0.15$ & $4.86 \pm 1.57$ & $4.21 \pm 0.11$ \\
\hline $\begin{array}{l}\text { Neochlo- } \\
\text { rogenic } \\
\text { acid }\end{array}$ & - & $37.48 \pm 0.85$ & $17.73 \pm 0.33$ & $17.86 \pm 0.49$ & $24.84 \pm 0.94$ & $24.34 \pm 0.93$ & $17.32 \pm 0.48$ & $13.44 \pm 0.49$ & $14.73 \pm 0.06$ \\
\hline $\begin{array}{l}\text { 3,4-Dihy- } \\
\text { droxyphe- } \\
\text { nylacetic } \\
\text { acid }\end{array}$ & $13.28 \pm 0.24$ & $107.19 \pm 2.24$ & $52.45 \pm 1.79$ & $66.59 \pm 3.10$ & $112.35 \pm 3.45$ & $99.85 \pm 4.13$ & $36.92 \pm 2.00$ & $53.59 \pm 4.13$ & $97.31 \pm 3.80$ \\
\hline $\begin{array}{l}\text { Chlorogenic } \\
\text { acid }\end{array}$ & $0.20 \pm 0.01$ & $52.40 \pm 1.95$ & $26.53 \pm 1.95$ & $48.73 \pm 3.33$ & $86.60 \pm 2.95$ & $96.68 \pm 2.59$ & $32.43 \pm 2.30$ & $201.61 \pm 2.23$ & $68.62 \pm 3.34$ \\
\hline Caffeic acid & - & $3.55 \pm 0.02$ & $1.74 \pm 0.01$ & $2.76 \pm 0.05$ & $1.79 \pm 0.02$ & $2.86 \pm 0.05$ & $1.64 \pm 0.03$ & $2.71 \pm 0.97$ & $2.69 \pm 0.03$ \\
\hline $\begin{array}{l}\text { Isochloro- } \\
\text { genic acid }\end{array}$ & $0.06 \pm 0.01$ & $6.56 \pm 0.59$ & $5.27 \pm 0.57$ & $8.36 \pm 0.50$ & $21.04 \pm 2.52$ & $19.42 \pm 2.35$ & $1.43 \pm 0.29$ & $112.47 \pm 7.25$ & $43.07 \pm 2.43$ \\
\hline $\begin{array}{l}\text { Rosmarinic } \\
\text { acid }\end{array}$ & $0.37 \pm 0.03$ & $81.71 \pm 5.10$ & $52.15 \pm 1.59$ & $56.33 \pm 1.05$ & $87.90 \pm 2.03$ & $106.28 \pm 1.42$ & $60.36 \pm 1.53$ & $1429.28 \pm 74.29$ & $546.92 \pm 34.90$ \\
\hline Sum & 13.91 & 297.08 & 163.51 & 203.45 & 349.12 & 364.25 & 158.66 & 1817.96 & 777.55 \\
\hline
\end{tabular}

G-shoots from ground plant, P1-shoot culture on MS without PGRs, P2—shoot culture on MS + BAP $1.0 \mathrm{mg} / \mathrm{L}, \mathrm{P} 3$ - shoot culture on $\mathrm{MS}+\mathrm{BAP} 1.0 \mathrm{mg} / \mathrm{L}+\mathrm{IAA} 0.5 \mathrm{mg} / \mathrm{L}+\mathrm{GA}_{3} 0.5 \mathrm{mg} / \mathrm{L}, \mathrm{P} 4$ - shoot culture on $\mathrm{MS}+\mathrm{BAP} 1.0 \mathrm{mg} / \mathrm{L}+\mathrm{IAA} 0.5 \mathrm{mg} / \mathrm{L}+\mathrm{GA}{ }_{3} 1.0 \mathrm{mg} / \mathrm{L}, \mathrm{P} 5 \mathrm{shoot}$ culture on $\mathrm{MS}+\mathrm{BAP} 1.0 \mathrm{mg} / \mathrm{L}+\mathrm{IAA} 1.0 \mathrm{mg} / \mathrm{L}+\mathrm{GA}_{3} 1.0 \mathrm{mg} / \mathrm{L}, \mathrm{PC} 1$ - shoots derived from callus $\mathrm{C} 1$ on regeneration medium $\mathrm{MS}+\mathrm{BAP}$ $1.0 \mathrm{mg} / \mathrm{L}+2,4-\mathrm{D} 1.0 \mathrm{mg} / \mathrm{L}, \mathrm{C} 1$ - callus on regeneration medium $\mathrm{MS}+\mathrm{BAP} 1.0 \mathrm{mg} / \mathrm{L}+2,4-\mathrm{D} 1.0 \mathrm{mg} / \mathrm{L}, \mathrm{C} 2$ - callus on induction medium $\mathrm{MS}+\mathrm{Dic} 1.0 \mathrm{mg} / \mathrm{L}+\mathrm{TDZ} 0.5 \mathrm{mg} / \mathrm{L}$ 
Fig. 2 The representative HPLC-UV chromatogram $(\lambda=$ $254 \mathrm{~nm}$ ) of Eryngium alpinum L. in vitro shoot extract: 1 - caftaric acid, 2-neochlorogenic acid, 3-3,4-dihydroxyphenylacetic acid, 4-chlorogenic acid, 5-caffeic acid, 6isochlorogenic acid, 7-isoquercetin, 8-rosmarinic acid, 9-quercitrin

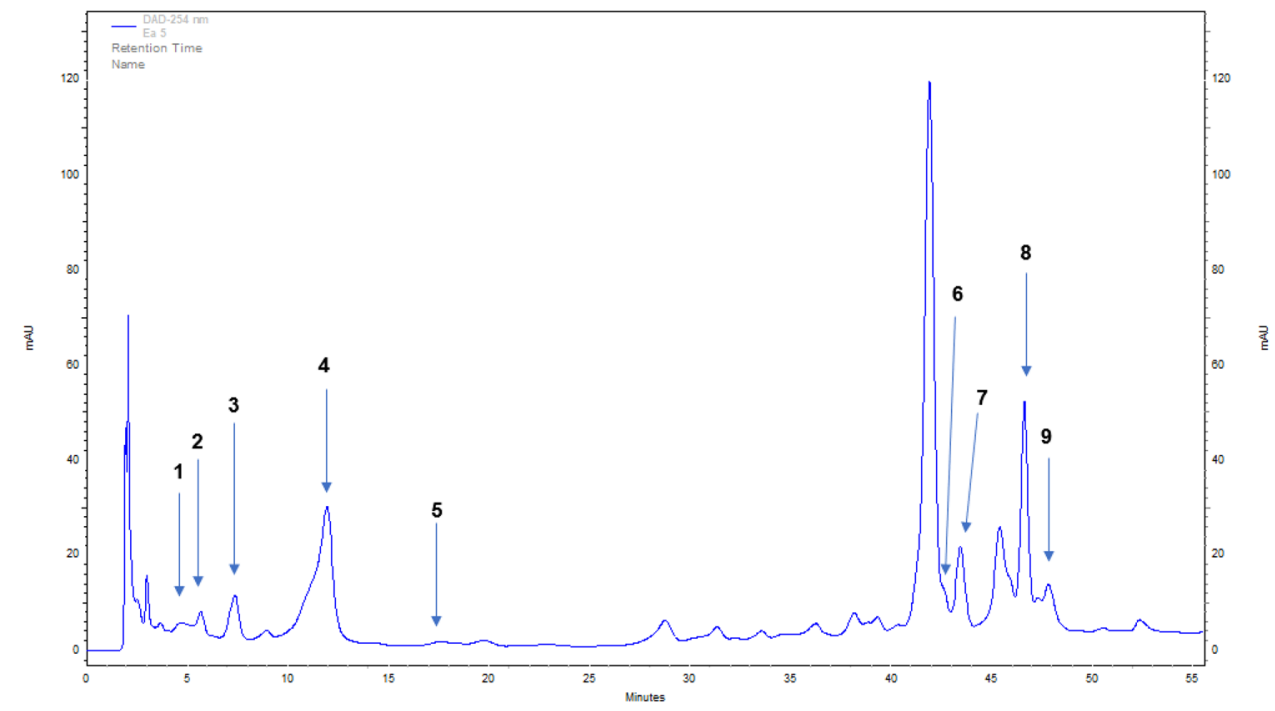

Fig. 3 The representative HPLC-UV chromatogram $(\lambda=$ $254 \mathrm{~nm}$ ) of Eryngium alpinum L. callus extract: 1 - caftaric acid, 2-neochlorogenic acid, 3-3,4-dihydroxyphenylacetic acid, 4-chlorogenic acid, 5caffeic acid, 6-isochlorogenic acid, 7—rosmarinic acid

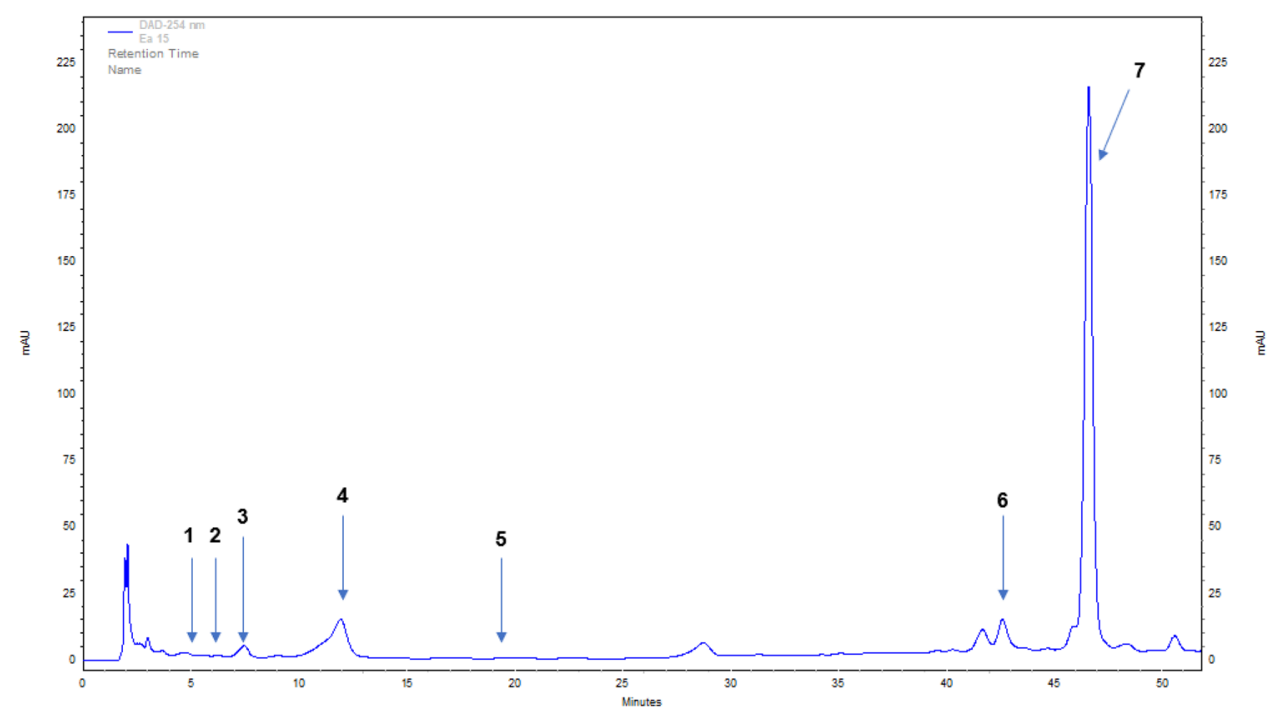

Table 5 The content of selected flavonoids in the shoot cultures and callus of Eryngium alpinum L.

Flavonoids Shoots $(\mathrm{mg} / 100 \mathrm{~g} \mathrm{DW})$

\begin{tabular}{lllllllll}
\hline G & P1 & P2 & P3 & P4 & P5 & PC1 & C1 & C2 \\
\hline $4.47 \pm 0.46$ & $11.10 \pm 0.45$ & $8.10 \pm 0.26$ & $8.27 \pm 0.32$ & $17.81 \pm 1.95$ & $20.03 \pm 0.98$ & $9.70 \pm 0.65$ & - & - \\
- & $36.09 \pm 0.10$ & $22.47 \pm 0.92$ & $22.27 \pm 0.86$ & $33.34 \pm 1.30$ & $31.27 \pm 1.76$ & $19.60 \pm 0.17$ & - & - \\
4.47 & 47.19 & 30.57 & 30.54 & 51.15 & 51.30 & 29.30 & - & - \\
\hline
\end{tabular}

G-shoots from ground plant, P1—shoot culture on MS without PGRs, P2—shoot culture on MS + BAP 1.0 mg/L, P3—shoot culture on $\mathrm{MS}+\mathrm{BAP} 1.0 \mathrm{mg} / \mathrm{L}+\mathrm{IAA} 0.5 \mathrm{mg} / \mathrm{L}+\mathrm{GA}_{3} 0.5 \mathrm{mg} / \mathrm{L}, \mathrm{P} 4$ - shoot culture on $\mathrm{MS}+\mathrm{BAP} 1.0 \mathrm{mg} / \mathrm{L}+\mathrm{IAA} 0.5 \mathrm{mg} / \mathrm{L}+\mathrm{GA} 31.0 \mathrm{mg} / \mathrm{L}, \mathrm{P} 5 \mathrm{shoot}$ culture on MS + BAP $1.0 \mathrm{mg} / \mathrm{L}+\mathrm{IAA} 1.0 \mathrm{mg} / \mathrm{L}+\mathrm{GA}_{3} 1.0 \mathrm{mg} / \mathrm{L}, \mathrm{PC} 1$-shoots derived from callus $\mathrm{C} 1$ on regeneration medium $\mathrm{MS}+\mathrm{BAP}$ $1.0 \mathrm{mg} / \mathrm{L}+2,4-\mathrm{D} 1.0 \mathrm{mg} / \mathrm{L}, \mathrm{C} 1-$ callus on regeneration medium $\mathrm{MS}+\mathrm{BAP} 1.0 \mathrm{mg} / \mathrm{L}+2,4-\mathrm{D} 1.0 \mathrm{mg} / \mathrm{L}, \mathrm{C} 2-$ callus on induction medium MS + Dic $1.0 \mathrm{mg} / \mathrm{L}+\mathrm{TDZ} 0.5 \mathrm{mg} / \mathrm{L}$ 
medium, containing PGRs (BAP and NAA). The total contents of the examined metabolites in the biomass of shootdifferentiating callus ranged from 14.90 to $60.05 \mathrm{mg} / 100 \mathrm{~g}$ DW. The total content of the compounds in the biomass from the callus culture was higher and amounted to 74.54 and $78.24 \mathrm{mg} / 100 \mathrm{~g}$ DW. The maximum total contents of phenolic acids in both types of the in vitro cultures were greater than in the leaves $(4.55 \mathrm{mg} / 100 \mathrm{~g} \mathrm{DW})$ of the parent plants (Szopa and Ekiert 2012). In the studies on the callus of Anethum graveolenes (Szopa and Ekiert 2015) maintained on the LS medium (Linsmaier and Skoog 1965), variants differing in the PGRs content, the high amounts of PAs, the maximum total amounts of phenolic acids obtained in the in vitro grown biomass were slightly higher than their amounts in the fruits of the parent plant analyzed for comparison $(99.66 \mathrm{mg} / 100 \mathrm{~g} \mathrm{DW}$ and $93.34 \mathrm{mg} / 100 \mathrm{~g} \mathrm{DW}$, respectively). On the other hand, the studies on PAs accumulation performed on Aronia species, i.e. A. melanocarpa and A. arbutifolia and their hybrid, i.e. A. $\times$ prunifolia, showed that the shoot cultures proved to produce higher amounts of PAs, especially of depsides (CGA, RA and neochlorogenic acid), than the callus. In the shoot cultures of A. melanocarpa grown on the MS media, the amounts of PAs were from 1.57 to 4.12 times higher than in the biomass from the callus (Szopa et al. 2013; Szopa and Ekiert 2014). The total amounts of the estimated compounds for A. arbutifolia were from 1.12 to 3.07 times and for $A$. $\times$ prunifolia from 2.71 to 9.11 times higher in the shoots than in the calluses growing on identical MS variants (Szopa et al. 2018).

The content of flavonoids in E. alpinum was significantly higher (from 6.8 to 11.48 times) in the shoots cultured in vitro than in the shoots from the ground plant and depended on a medium hormonal variant. The flavonoid content increased with higher $\mathrm{GA}_{3}$ concentration. The qualitative differences were confirmed: quercitrin was absent in the control shoots (the soil-grown plant), but the callus did not produce flavonoids at all. The shoots regenerated from the callus were able to produce flavonoids in contrast to callus tissue, from which they derived (Table 5). The absence of flavonoids in the callus cultures of some plants, including a related species-Eryngium planum, was recorded (Thiem et al. 2001; Budzianowska et al. 2004; Kikowska et al. 2012).

\section{Conclusion}

In vitro cultures of Eryngium alpinum L. were initiated and established for the first time. Moreover, in vitro culture of genetically uniform shoots developed via axillary buds may be the method of ex situ conservation of this endangered and protected species. The shoot and callus biomass can be considered as a valuable alternative source of desired polyphenols.

Author contributions M.K. is the author of conception, who design the study, initiated and maintained the in vitro cultures of Eryngium alpinum L., and wrote the manuscript. M.K. and B.T. collected the plant material. M.R. and E.S. estimated the genome size of the plant material. A.S., M.K.-S. performed and elaborated the phytochemical analyses. H.E. corrected and improved the manuscript. All the authors contributed to data interpretation, critical revision of the manuscript and its final approval.

\section{Compliance with ethical standards}

Conflict of interest The authors declare that they have no conflict of interest.

Open Access This article is distributed under the terms of the Creative Commons Attribution 4.0 International License (http://creativeco mmons.org/licenses/by/4.0/), which permits unrestricted use, distribution, and reproduction in any medium, provided you give appropriate credit to the original author(s) and the source, provide a link to the Creative Commons license, and indicate if changes were made.

\section{References}

Andrello M, Devaux C, Quetier F, Till-Bottraud I (2017) Paying for conservation: a bioeconomic analysis of the effects of land management options on the viability of an endangered species, Eryngium alpinum. J Appl Ecol 55:1940-1950. https://doi. org/10.1111/1365-2664.13112

Arockiasamy S, Ignacimuthu S (1998) Plant regeneration from mature leaves and roots of Eryngium foetidum L., a food flavouring agent. Curr Sci 75:664-666

Arockiasamy S, Prakash S, Ignacimuthu S (2002) Direct organogenesis from mature leaf and petiole explants of Eryngium foetidum L. Biol Plant 45:129-132. https://doi.org/10.1023/A:101517733

Ayuso M, García-Pérez P, Ramil-Rego P, Gallego PP, Barreal ME (2019) In vitro culture of the endangered plant Eryngium viviparum as dual strategy for its ex situ conservation and source of bioactive compounds. Plant Cell Tiss Organ Cult. https://doi. org/10.1007/s11240-019-01638-y

Budzianowska A, Skrzypczak L, Budzianowski J (2004) Phenylethanoid glucosides from in vitro propagated plants and callus cultures of Plantago lanceolata. Planta Med 70:834-840. https://doi. org/10.1055/s-2004-827232

Chandrika R, Vyshali P, Saraswathi KJT, Kaliwal BB (2011) Rapid multiplication of mature flowering plant of Eryngium foetidum L. by in vitro technique. IJBA 3:114-117. https://doi. org/10.9735/0975-2975-2943.3.4.114-117

Crowden RK, Harborne JB, Heywood VH (1969) Chemosystematics of the umbelliferae: a general survey. Phytochemistry 8:1963-1984. https://doi.org/10.1016/S0031-9422(00)88084-x

Cullen J, Alexander JCM, Brady A, Brickell CD, Green PS, Heywood VH, Jörgensen PM, Jury SL, Knees SG, Leslie AC, Matthews VA, Robson NKB, Walters SM, Wijnands DO, Yeo PF (1997) The European garden flora, vol 5. Cambridge University Press, London, pp 396-398

Dunkic V, Vuko E, Bezic N, Kremer D, Ruscic M (2013) Composition an antiviral activity of the essential oils of Eryngium alpinum 
and E. amethystinum. Chem Biodivers 10:1894-1902. https://doi. org/10.1002/cbdv.201300061

Ellnain-Wojtaszek M, Zgorka G (1999) High-performance liquid chromatography and thin-layer chromatography of phenolic acids from Ginkgo biloba $\mathrm{L}$. leaves collected within vegetative period. J Liq Chromatogr Relat Technol 22:1457-1471. https:// doi.org/10.1081/JLC-100101744

Galbraith DW, Harkins KR, Maddox JM, Ayres NM, Sharma DP, Firoozabady E (1983) Rapid flow cytometric analysis of the cell cycle in intact plant tissues. Science 220:1049-1051. https://doi. org/10.1126/science.220.4601.1049

Gygax A, Bernhardt KG, Jogan N, Montagnani C, Gigot G (2013) Eryngium alpinum. In: The IUCN Red List of threatened species. Version 2014.3

Ignacimuthu S, Arockiasamy S, Antonysamy M, Ravichandran P (1999) Plant regeneration through somatic embryogenesis from mature leaves of Eryngium foetidum L.: a condiment. Plant Cell, Tissue Organ Cult 56:131-137. https://doi.org/10.1023/A:10062 28310864

Kikowska M, Budzianowski J, Krawczyk A, Thiem M (2012) Accumulation of rosmarinic, chlorogenic and caffeic acids in in vitro cultures of Eryngium planum L. Acta Physiol Plant 34:2425-2433. https://doi.org/10.1007/s11738-012-1011-1

Kikowska M, Thiem B, Sliwinska E, Rewers M, Kowalczyk M, Stochmal A, Oleszek W (2014) The effect of nutritional factors and plant growth regulators on micropropagation and production of phenolic acids and saponins from plantlets and adventitious root cultures of Eryngium maritimum L. J Plant Growth Regul 33:809-819. https://doi.org/10.1007/s0034 4-014-9428-y

Kikowska M, Kędziora J, Krawczyk A, Thiem B (2015) Methyl jasmonate, yeast extract and sucrose stimulate phenolic acids accumulation in Eryngium planum L. shoot cultures. Acta Biochim Pol 62:197-200. https://doi.org/10.18388/abp.2014_880

Kikowska M, Thiem B, Sliwinska E, Rewers M, Kowalczyk M, Stochmal A, Długaszewska J (2016) Micropropagation of Eryngium campestre $\mathrm{L}$. via shoot culture provides valuable uniform plant material with enhanced content of phenolic acids and antimicrobial activity. Acta Biol Cracov Bot 58:43-56. https://doi. org/10.1515/abcsb-2016-0009

Le Claire E, Schwaiger S, Banaigs B, Stuppner H, Gafner F (2005) Distribution of a new rosmarinic acid derivative Eryngium alpinum L. and other Apiaceae. J Agric Food Chem 53:4367-4372. https ://doi.org/10.1021/ji050024v

Linsmaier EM, Skoog F (1965) Organic growth factor requirements of tobacco tissue cultures. Physiol Plant 18:100-127. https://doi. org/10.1111/j.1399-3054.1965.tb06874.x

Marie D, Brown SC (1993) A cytometric exercise in plant histograms, with $2 \mathrm{C}$ values for 70 species. Biol Cell 78:41-51. https://doi. org/10.1016/0248-4900(93)90113-S

Martin KP (2004) Efficacy of different growth regulators at different stages of somatic embryogenesis in Eryngium foetidum L.: a rare medicinal plant. In Vitro Cell Dev Biol 40:459-463. https://doi. org/10.1079/IVP2004543

Murashige T, Skoog F (1962) A revised medium for rapid growth and bioassays with tobacco cultures. Physiol Plant 15:473-497. https ://doi.org/10.1111/j.1399-3054.1962.tb08052.x

Njenga J (1995) Production of Eryngium. N.C Flower Grow Bull 40:9-11
Petrova M, Zayova E, Yankova E, Baldzhiev G (2011) Plant regeneration from callus culture of Arnica montana. Rom Biotechnol Lett 16(1):92-97

Rahman A, Othman A, Kamaruddin F, Ahmad A (2015) Direct shoot regeneration from callus of Melicope lunu-ankenda. Nat Sci 7:8187. https://doi.org/10.4236/ns.2015.72009

Sharma A, Bhansali S, Kumar A (2013) In vitro callus induction and shoot regeneration in Eclipta alba (L.) Hassk. Int J Life Sci Pharma Res 3(2):42-46

Sułkowska-Ziaja K, Maślanka A, Szewczyk A, Muszyńska B (2017) Physiologically active compounds in four species of Phellinus. Nat Prod Commun 12:363-366

Szopa A, Ekiert H (2012) In vitro cultures of Schisandra chinensis (Turcz.) Baill. (Chinese magnolia vine): a potential biotechnological rich source of therapeutically important phenolic acids. Appl Biochem Biotechnol 166:1941-1948. https://doi.org/10.1007/ s12010-012-9622-y

Szopa A, Ekiert H (2014) Production of biologically active phenolic acids in Aronia melanocarpa (Michx.) Elliott in vitro cultures cultivated on different variants of the Murashige and Skoog medium. Plant Growth Regul 72:51-58. https://doi.org/10.1007/ s10725-013-9835-2

Szopa A, Ekiert H (2015) Anethum graveolens L. in vitro cultures: a potential source of bioactive metabolites, phenolic acids and furanocoumarins. Acta Biol Cracov Ser Bot 57:29-37. https:// doi.org/10.1515/abcsb-2015-0016

Szopa A, Ekiert H, Muszyńska B (2013) Accumulation of hydroxybenzoic acids and other biologically active phenolic acids in shoot and callus cultures of Aronia melanocarpa (Michx.) Elliott (black chokeberry). Plant Cell, Tissue Organ Cult 113:323-329. https:// doi.org/10.1007/s11240-012-0272-0

Szopa A, Kokotkiewicz A, Bednarz M, Luczkiewicz M, Ekiert H (2017a) Studies on the accumulation of phenolic acids and flavonoids in different in vitro culture systems of Schisandra chinensis (Turcz.) Baill. using a DAD-HPLC method. Phytochem Lett 20:462-469. https://doi.org/10.1016/j.phytol.2016.10.016

Szopa A, Kokotkiewicz A, Kubica P, Banaszczak P, WojnatowskaKrośniak A, Krośniak M, Marzec-Wróblewska U, Badura A, Zagrodzki P, Buciński A, Luczkiewicz M, Ekiert H (2017b) Comparative analysis of different groups of phenolic compounds in fruit and leaf extracts of Aronia sp.: A. melanocarpa, A. arbutifolia, and $A$. × prunifolia and their antioxidant activities. Eur Food Res Technol. https://doi.org/10.1007/s00217-017-2872-8

Szopa A, Kubica P, Snoch A, Ekiert H (2018) High production of bioactive depsides in shoot and callus cultures of Aronia arbutifolia and Aronia $\times$ prunifolia. Acta Physiol Plant 40:48. https:// doi.org/10.1007/s11738-018-2623-x

Thiem B, Wesołowska M, Skrzypczak L, Budzianowski J (2001) Phenolic compounds in two Solidago L. species from in vitro culture. Acta Pol Pharm 58:277-281

Thiem B, Kikowska M, Krawczyk A, Więckowska B, Sliwinska E (2013) Phenolic acid and DNA contents of micropropagated Eryngium planum L. Plant Cell, Tissue Organ Cult 114:197-206. https ://doi.org/10.1007/s11240-013-0315-1

Publisher's Note Springer Nature remains neutral with regard to jurisdictional claims in published maps and institutional affiliations. 